Jurnal Ilmiah Matematika dan Pendidikan Matematika (JMP)

Vol. 9 No. 2, Desember 2017, hal. 49-62

ISSN (Cetak) : 2085-1456; ISSN (Online) : 2550-0422; https://jmpunsoed.com/

\title{
KEMAMPUAN MAHASISWA PENDIDIKAN MATEMATIKA DALAM MEMECAHKAN MASALAH DI AWAL DAN AKHIR SEMESTER PERTAMA
}

\author{
Jackson Pasini Mairing \\ Dosen Pendidikan Matematika FKIP Universitas Palangka Raya \\ jacksonmairing@gmail.com
}

\begin{abstract}
Problem solving ability is main goal of students in learning mathematics. Lectures should be able to improve the ability. This reasearch aimed to describe ability of students at the beginning and end of first semester academic year 2016/2017 in solving mathematical problems. The research subjects were 71 students of mathematics education program class of 2016 from one of the universities in Central Kalimantan, Indonesia. At the beginning and the end of first semester, each subject was given six mathematical problems. The problems at the beginning and the end of semester were similar only differently in numbers. The result showed that average score of the students at the beginning and the end of first semester were 7.97 and 9.18 (scale 0 - 24) respectively. The scores increased significantly with a 95\% confidence level. The increasng caused $8.4 \%$ of the students who were classified as naive problem solvers increased their ability becomed routine problem solvers. No students have improved their ability becomed good problem solvers.
\end{abstract}

Keywords: mathematical problems, problem solving, problem solver, mathematical lecturer

\begin{abstract}
ABSTRAK. Kemampuan untuk memecahkan masalah merupakan tujuan utama mahasiswa dalam belajar matematika. Perkuliahan sebarusnya dapat meningkatkan kemampuan tersebut. Penelitian ini bertujuan untuk mendeskripsikan kemampuan mahasiswa di awal dan akhir semester pertama tahun ajaran 2016/2017 dalam memecahkan masalah matematika. Subjek penelitiannya adalah 71 mahasiswa program studi pendidikan matematika angkatan 2016 dari salah satu universitas di Kalimantan Tengah. Pada awal dan akhir semester pertama, semua subjek diberikan masing-masing enam masalah matematika. Masalah di awal dan akhir tersebut serupa hanya berbeda pada bilangan-bilangannya. Hasilnya adalah rata-rata skor mahasiswa dalam memecahkan masalah di awal dan akhir semester pertama secara berturut-turut sebesar 7,97 dan 9,18 (skala 0 - 24). Terjadi peningkatan skor tersebut secara signifikan dengan tingkat kepercayaan 95\%. Peningkatan tersebut menyebabkan 8,4\% mahasiswa yang tergolong pemecah masalah yang kurang berpengalaman meningkat kemampuannya menjadi pemecah masalah yang rutin. Tidak ada mahasiswa yang meningkat kemampuannya menjadi pemecah masalah yang baik.
\end{abstract}

Kata kunci: masalah matematika, pemecahan masalah, pemecah masalah, perkuliahan matematika 


\section{PENDAHULUAN}

Tujuan utama mahasiswa belajar matematika adalah mengembangkan kemampuan berpikir matematisnya (National Council of Teachers of Mathematics, 2000). Tujuan tersebut dapat dicapai mahasiswa dengan belajar memecahkan masalah-masalah matematika. Masalah berbeda dengan soal rutin (Van De Walle, Karp, \& Bay-Williams, 2010). Pada soal rutin, jawabannya dapat diperoleh mahasiswa secara langsung dengan menyebutkan atau menerapkan suatu rumus/prosedur tertentu. Kemampuan mahasiswa dalam menyebutkan tersebut tergolong berpikir memanggil, sedangkan kemampuan dalam menerapkan tergolong berpikir dasar. Kedua kemampuan tersebut tergolong berpikir tingkat rendah (Krulik, Rudnick, \& Milou, 2003). Contoh soal rutin yang menuntut kemampuan berpikir memanggil adalah "tuliskan definisi dari $f \circ$ $g(x)$ ", sedangkan contoh soal rutin dengan berpikir dasar adalah "misalkan $f(x)=2 x$ dan $g(x)=x-1$, tentukan $f \circ g(x)$ ".

Pada masalah, jawabannya tidak dapat diperoleh mahasiswa secara langsung dengan menerapkan suatu rumus/prosedur tertentu. Hal tersebut membuat cara penyelesaian dari masalah tidak segera dapat dilihat oleh mahasiswa. Penyelesaian masalah membutuhkan kemampuan berpikir kritis atau kreatif. Keduanya tergolong berpikir tingkat tinggi (King, Goodson, \& Rohani, 2016). Pemecahan masalah membutuhkan kemampuan tersebut karena mahasiswa perlu melakukan aktivitas-aktivitas kognitif mulai dari memahami masalah, membuat rencana penyelesaian, melaksanakan rencana, dan memeriksa kembali (Kennedy, Tipps, \& Johnson, 2008; Musser, Burger, \& Peterson, 2011; Polya, How to solve it, 1973). Contoh masalah adalah "misalkan $g(x)=2 x+5$ dan $g \circ f(x)=3 x^{2}+7$, tentukan nilai $f(0)$ ". Dengan demikian, kemampuan berpikir tingkat tinggi dapat dimiliki mahasiswa melalui pemecahan masalah matematika.

Mahasiswa juga dapat mengembangkan sikap-sikap positif melalui belajar memecahkan masalah matematika (Marzano, Pickering, \& McTighe, 1993). Masalah matematika itu sendiri didefinisikan sebagai suatu soal dimana cara menyelesaikannya tidak segera dapat dilihat oleh mahasiswa. Ini karena penyelesaian masalah matematika membutuhkan waktu dan aktivitas kognitif 
tertentu (Mairing, Budayasa, \& Juniati, 2012). Implikasinya adalah mahasiswa belum tentu dapat menyelesaikan masalah matematika pada waktu pertama kali mencobanya. Mahasiswa perlu belajar dan mencoba kembali untuk menyelesaikan masalah tersebut. Jika belum berhasil, mahasiswa perlu belajar dan mencoba lagi hingga masalah tersebut dapat diselesaikan. Proses tersebut membuat mahasiswa memiliki salah satu sikap positif yaitu tekun dan pantang menyerah. Bukan hanya itu. mahasiswa juga dapat mengembangkan sikap-sikap positif lainnya yaitu percaya diri dalam menghadapi situasi yang tidak biasa dan keingintahuan yang besar (Mairing, Budayasa, \& Juniati, 2011)

Keuntungan lain dari belajar menyelesaikan masalah matematika adalah mahasiswa membuat hubungan antara konsep-konsep matematika, menggunakan konsep-konsep tersebut dalam konteks yang bermakna; mengembangkan kemampuan bernalar dengan mengeksplorasi ide-ide matematika; membuat konjektur dan menjustifikasi hasilnya; melatih mahasiswa untuk bekerja sama dalam menentukan cara-cara dalam menyelesaikan masalah, menkomunikasikan dan mendengarkan mahasiswa lainnya mengenai ide-ide dan hasil-hasilnya; belajar merepresentasikan kondisi dari masalah menggunakan gambar, tabel, diagram, bilangan, kalimat atau simbol (Florida Deparment of Education, 2010; Ministry of Education, 2006).

Pentingnya masalah matematika di atas belum sesuai dengan fakta pada mahasiswa program studi Pendidikan Matematika dari salah satu universitas di Kalimantan Tengah. Pada awal semester 1, peneliti membagikan enam masalah awal berikut kepada mahasiswa tersebut. Hasilnya menunjukkan bahwa rata-rata kemampuan mahasiswa dalam memecahkan masalah sebesar 7,97 (skala 0 - 24). Lebih lanjut, tidak ada mahasiswa yang memperoleh skor 4 di setiap masalah.

Materi-materi dari mata kuliah di semester 1 diharapkan dapat membantu mahasiswa dalam memahami konsep-konsep yang terkait dengan masalah awal dan dalam meningkatkan kemampuan berpikirnya. Mata kuliah tersebut adalah Pengantar Dasar Matematika dan Kalkulus 1. Akan tetapi, kemampuan dalam memecahkan masalah bukan hnaya dipengaruhi oleh pemahaman konsep dan kemampuan berpikir. Ada faktor-faktor lainnya seperti kebiasaan guru dalam 
kelas, motivasi mahasiswa dalam belajar, dan sikap mahasiswa dalam belajar dan memecahkan masalah.

Kondisi tersebut memunculkan pertanyaan: apakah kemampuan mahasiswa program studi pendidikan matematika angkatan 2016 dalam memecahkan masalah meningkat setelah belajar materi-materi dalam mata kuliah yang ada di semester pertama? Penelitian ini bertujuan untuk mendeskripsikan kemampuan mahasiswa angkatan 2016 dalam memecahkan masalah matematika di awal dan akhir semester pertama tahun ajaran 2016/2017, dan menguji signifikansi peningkatan kemampuan tersebut di awal dan akhir semester pertama. Hasil penelitian ini dapat dimanfaatkan oleh dosen dan ketua program studi untuk menilai efektivitas mata kuliah yang ada di semester pertama, dan pembelajarannya dalam meningkatkan kemampuan mahasiswa dalam memecahkan masalah-masalah matematika.

\section{METODE PENELITIAN}

Penelitian ini menggunakan pendekatan kuantitatif. Rancangan penelitiannya adalah tes sebelum dan sesudah mahasiswa menempuh mata kuliahmata kuliah di semester 1 . Penelitian ini dilaksanakan pada populasinya yaitu mahasiswa program studi pendidikan matematika angkatan 2016 dari salah satu universitas di Kalimantan Tengah. Mahasiswa-mahasiswa tersebut terbagi dalam kelas A dan B dengan banyak mahasiswa secara berturut-turut adalah 40 dan 31.

Tahap-tahap penelitiannya terdiri dari empat tahap (Cohen, Manion, \& Morrison, 2007; Lodico, Spaulding, \& Voegtle, 2006). Tahap pertama, peneliti merumuskan hipotesis penelitian yaitu ada peningkatan dari rata-rata skor awal $\left(\mu_{\mathrm{AWAL}}\right)$ ke rata-rata skor akhir $\left(\mu_{\mathrm{AKHIR}}\right)$. Skor dikatakan meningkat jika selisih skor akhir dari awal $(D)$ lebih dari nol. Dengan demikian hipotesis dalam penelitian ini adalah.

$$
\begin{aligned}
& H_{0}: D \leq 0 \\
& H_{1}: D>0
\end{aligned}
$$

dengan $D=\mu_{\mathrm{AKHIR}}-\mu_{\mathrm{AWAL}}$. 
Tahap kedua, peneliti mengembangkan instrumen penelitian yaitu masalah akhir untuk kelas A dan B. Masalah akhir serupa dengan masalah awal hanya berbeda pada bilangan-bilangannya. Ada enam masalah pada masalah akhir tersebut dimana masalah 1 sampai 5 adalah masalah tertutup (closed problem). Masalah 6 adalah masalah berakhir terbuka (open ended problem). Masalah tertutup adalah masalah yang memiiki tepat satu jawaban. Masalah berakhir terbutka adalah masalah yang memiliki lebih dari satu jawaban (Bush \& Greer, 1999). Materi-materi yang terkait dengan masalah tersebut adalah fungsi dan barisan. Kedua materi tersebut telah dipelajari sejak sekolah menengah atas, dan dipelajari kembali oleh mahasiswa di tahun pertama. Masalah akhir tersebut adalah sebagai berikut.

1. Misalkan $f(x)=4 x-3$ dan $g(x)=\sqrt{x}$ dan $f \circ g(x)=9$. Tentukan nilai $x$. Jelaskan jawabanmu!

2. Misalkan $g(x)=2 x+5$ dan $g \circ f(x)=3 x^{2}+7$. Tentukan nilai (0) ! Jelaskan jawabanmu!

3. Diketahui $a+(a+1)+(a+2)+\cdots+50=1.155$ dengan $a$ adalah bilangan positif. Tentukan nilai $a$ ! Jelaskan jawabanmu!

4. Pada suatu barisan aritmetika diketahui.nilai suku ke-25 adalah tiga kali suku ke-5. Tentukan suku keberapa yang nilainya tiga kali suku ke-1 ! Jelaskan jawabanmu!

5. Suatu fungsi kuadrat memiliki nilai minimum -7 di $x=-1$, dan melalui titik $(1,1)$. Tentukan persamaan fungsi tersebut! Jelaskan jawabanmu!

6. a. Suatu fungsi kuadrat yang grafiknya terbuka ke atas memiliki sumbu simetri di $x=-2$. Fungsi tersebut memiliki nilai 3 di $x=1$. Tentukan persamaan fungsi tersebut! Jelaskan jawabanmu!

b. Adakah persamaan lainnya dari fungsi tersebut? Jika ada, tentukan persamaan tersebut! Jelaskan jawabanmu!

Tahap ketiga, peneliti memberikan masalah akhir tersebut di kedua kelas. Setiap penyelesaian mahasiswa diskor menggunakan rubrik holistik pemecahan masalah pada Tabel 1 (Charles, Lester, \& O'Daffer, 1987; Sa'dijah \& Sukoriyanto, 
2015). Maksimum skor setiap masalah adalah 4. Ada enam masalah sehingga maksimum skor setiap mahasiswa adalah $6 \times 4=24$.

Tabel 1. Rubrik Holistik Pemecahan Masalah

\begin{tabular}{|c|c|}
\hline Skor & Deskripsi \\
\hline 0 & $\begin{array}{l}\text { a. Mahaiswa tidak menulis apa pun pada lembar penyelesaian, } \\
\text { b. Mahasiswa menulis yang diketahui dan ditanya, tetapi tidak menunjukkan } \\
\text { pemahaman terhadap masalah. }\end{array}$ \\
\hline 1 & $\begin{array}{l}\text { a. Mahasiswa menulis yang diketahui dan ditanya dengan benar, ada langkah- } \\
\text { langkah penyelesaian, tetapi cara yang digunakan tidak sesuai. } \\
\text { b. Mahasiswa telah berusaha untuk mencapai subtujuan, tetapi tidak berhasil. } \\
\text { c. Mahasiswa menjawab dengan benar, tetapi tidak ada caranya. }\end{array}$ \\
\hline 2 & $\begin{array}{l}\text { a. Mahasiswa menggunakan cara yang tidak sesuai dan jawabannya salah, tetapi } \\
\text { penyelesaiannya menunjukkan beberapa pemahaman terhadap masalah. } \\
\text { b. Mahasiswa menulis jawaban yang benar, tetapi caranya tidak dapat } \\
\text { dipahami/salah. }\end{array}$ \\
\hline 3 & $\begin{array}{l}\text { a. Mahasiswa telah menerapkan suatu cara yang sesuai, tetapi salah memahami } \\
\text { bagian tertentu dari masalah, atau mengabaikan suatu kondisi dari masalah. } \\
\text { b. Mahasiswa telah menerapkan suatu cara penyelesaian yang sesuai, tetapi- } \\
\text { (i) menjawab masalah secara tidak benar tanpa penjelasan. } \\
\text { (ii) tidak menuliskan jawabannya. } \\
\text { c. Mahasiswa menuliskan jawaban benar, dan ada beberapa bukti yang } \\
\text { menunjukkan bahwa siswa tersebut telah memilih cara yang sesuai, tetapi } \\
\text { penerapan dari cara tersebut tidak sepenuhnya benar. }\end{array}$ \\
\hline 4 & $\begin{array}{l}\text { a. Mahasiswa telah menggunakan cara yang sesuai, mengimplementasikan } \\
\text { dengan benar, dan menuliskan jawaban yang benar. } \\
\text { b. Mahasiswa menggunakan cara yang sesuai, menulis jawaban yang benar, } \\
\text { tetapi ada sedikit kesalahan dalam perhitungan. }\end{array}$ \\
\hline
\end{tabular}

Tahap keempat, peneliti menganalisis data untuk menarik kesimpulan. Analisisnya menggunakan uji perbandingan dua sampel berpasangan. Uji tersebut menggunakan data $d$ =skor akhir - skor awal untuk setiap mahasiswa Asumsinya adalah data $d$ menyebar normal. Kenormalan tersebut diperiksa dengan uji Kolmogorov-Smirnov. Uji-uji tersebut dilakukan peneliti menggunakan program Minitab 17.

\section{HASIL PENELITIAN}

Peneliti membagikan masalah akhir ke semua mahasiswa di kelas A dan B. Masalah akhir di kedua kelas serupa hanya berganti bilangan-bilangannya. Masalah akhir juga serupa dengan masalah awal. Hasilnya menunjukkan rata-rata 
skor akhir lebih dari atau sama dengan skor awal di setiap masalah. Begitu pula, rata-rata total skor yang diperoleh siswa pada masalah akhir $(=9,18)$ lebih dari masalah awal $(=7,97)$ (Tabel 1). Terjadi peningkatan skor sebesar $15,2 \%$. Hasil serupa terjadi pada persentase siswa yang memperoleh skor 4 di setiap masalah dimana persentase tersebut pada masalah akhir lebih dari atau sama dengan masalah awal (Tabel 2).

Tabel 2. Rata-Rata Skor Siswa di Setiap Masalah dan Total Skor

\begin{tabular}{llllllll}
\hline Masalah & $\mathbf{1}$ & $\mathbf{2}$ & $\mathbf{3}$ & $\mathbf{4}$ & $\mathbf{5}$ & $\mathbf{6}$ & Total Skor \\
\hline Awal & 2,73 & 2,34 & 1,34 & 1,13 & 0,31 & 0,13 & 7,97 \\
Akhir & 3,13 & 2,48 & 1,34 & 1,10 & 0,86 & 0,28 & 9,18 \\
\hline
\end{tabular}

Kemampuan mahassiwa dalam memecahkan masalah dapat digolongkan menjadi pemecah masalah yang baik, rutin, atau tidak berpengalaman (Muir, Beswick, \& Williamson, 2008). Hasil penelitian menunjukkan bahwa tidak ada mahasiswa yang memperoleh skor 4 (menjawab benar) pada masalah 6 yang merupakan masalah berakhir terbuka baik di masalah awal maupun akhir (Tabel 3). Dengan kata lain, tidak ada mahasiswa yang memperoleh skor 4 di setiap masalah. Mahasiswa yang memperoleh skor tersebut digolongkan sebagai pemecah masalah yang baik. Jadi, tidak ada mahasiswa yang tergolong sebagai pemecah masalah ini baik di awal maupun akhir semester 1 (Tabel 4).

Tabel 3. Persentase Mahasiswa yang Memperoleh Skor 4

\begin{tabular}{lllllll}
\hline Masalah & $\mathbf{1}$ & $\mathbf{2}$ & $\mathbf{3}$ & $\mathbf{4}$ & $\mathbf{5}$ & $\mathbf{6}$ \\
\hline Awal & 46,5 & 36,6 & 14,1 & 11,3 & 2,8 & 0 \\
Akhir & 54,9 & 42,3 & 18,3 & 14,1 & 8,5 & 0 \\
\hline
\end{tabular}

Persentase mahasiswa yang memperoleh skor 0 atau 1 di setiap masalah pada masalah awal dan akhir secara berturut-turut sebesar 16,9\% dan 8,5\%. Mahasiswa yang memperoleh skor tersebut digolongkan sebagai pemecah masalah yang kurang berpengalaman. Perkuliahan di semester 1 dapat 
mengurangi mahasiswa yang tergolong pemecah yang kurang berpengalaman atau menambah pemecah masalah yang rutin sebanyak 8,4\%, tetapi belum dapat meningkatkan kemampuan mahasiswa menjadi pemecah masalah yang baik (Tabel 4).

Tabel 4. Persentase Mahasiswa di Setiap Kemampuan Pemecahan Masalah

\begin{tabular}{llll}
\hline Masalah & \multicolumn{3}{l}{ Pemecah masalah } \\
\cline { 2 - 4 } & Baik & Rutin & Kurang berpengalaman \\
\hline Awal & 0 & 83,1 & 16,9 \\
Akhir & 0 & 91,5 & 8,5 \\
\hline
\end{tabular}

Hipotesis dalam penelitian ini diuji menggunakan uji perbandingan dua sampel berpasangan. Peneliti terlebih dahulu menentukan selisih $D=$ skor akhir - skor awal untuk setiap mahasiswa. Uji kenormalan KolmogorovSmirnov dari data ini dilakukan peneliti menggunakan Minitab 17. Hasilnya adalah $p-$ value $=0,082 \geq 0,05=\alpha$ (Gambar 1$)$. Ini berarti data $d$ menyebar normal (asumsi terpenuhi).

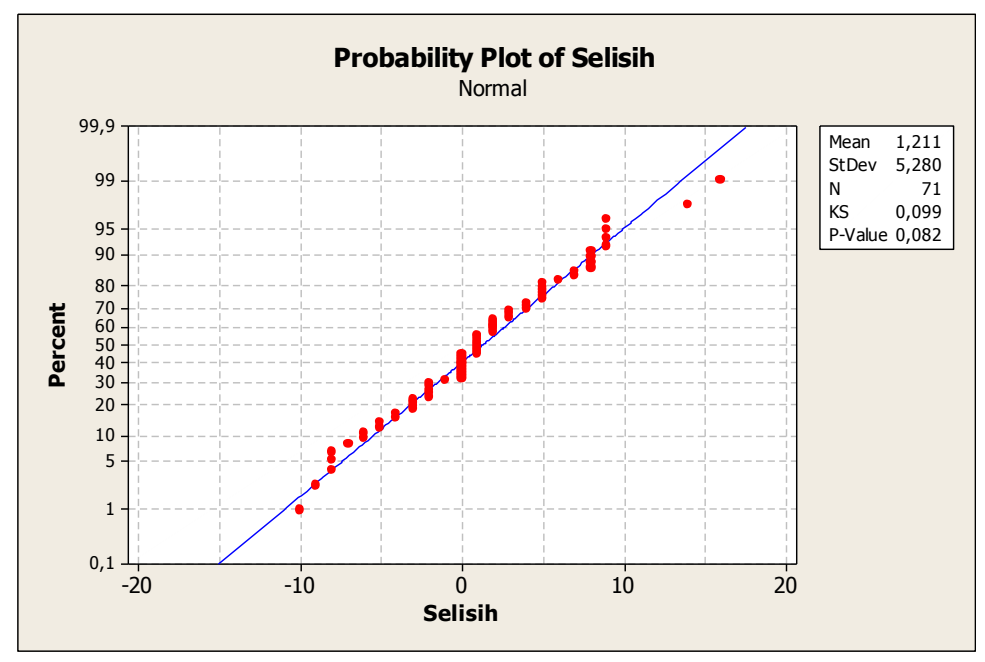

Gambar 1. Uji Kenormalan data $d$ 
Hasil uji hipotesis menunjukkan rata-rata data selisih $\bar{x}_{D}=1,211$ dan $p$-value $=0,029<0,05=\alpha$ (Tabel 5). Ini berarti data mendukung untuk menolak hipotesis nol yang berarti skor mahasiswa pada masalah akhir lebih dari masalah awal. Dengan kata lain, terjadi peningkatan skor kemampuan mahasiswa dalam memecahkan masalah matematika dari awal ke akhir semester 1 secara signifikan dengan tingkat kepercayaan $95 \%$.

Tabel 5. Hasil Uji Perbandingan Dua Sampel Berpasangan

\begin{tabular}{cccccccc}
\hline Variable & $\mathbf{N}$ & Mean & StDev & SE Mean & $\mathbf{9 5 \%}$ Lower Bound & $\mathbf{T}$ & $\mathbf{p}$ \\
\hline Selisih & 71 & 1,211 & 5,280 & 0,627 & 0,167 & 1,93 & 0,029 \\
\hline
\end{tabular}

\section{PEMBAHASAN}

Hasil penelitian menunjukkan bahwa terjadi peningkatan skor mahasiswa dalam memecahkan masalah matematika setelah belajar di semester 1. Akan tetapi, peningkatan tersebut terjadi pada mahasiswa yang tergolong pemecah masalah yang kurang berpengalaman dimana ada 8,4\% dari pemecah masalah ini yang kemampuannya meningkat menjadi pemecah masalah yang rutin. Kondisi tersebut terjadi karena ada faktor-faktor lain yang mempengaruhi kemampuan mahasiswa dalam memecahkan masalah selain pemahaman terhadap materimateri yang terkait dengan masalah. Faktor-faktor tersebut antara lain motivasi mahasiswa dalam belajar, kepercayaan diri mahasiswa, pengetahuan mengenai strategi-strategi dan pendekatan dalam pemecahan masalah, dan pengalaman mahasiswa dalam memecahkan masalah (Lerch, 2004; Pimta, Tayruakham, \& Nuangchalerm, 2009).

Beberapa hasil penelitian menunjukkan bahwa kebiasaan dan metode yang digunakan guru dalam kelas mempengaruhi kemampuan siswa-siswa dalam memecahkan masalah (ahli). Guru yang menyediakan waktu yang lebih banyak bagi siswa untuk belajar memecahkan masalah-masalah, maka kemampuannya lebih tinggi dibandingkan guru yang menyediakan waktu lebih banyak pada pemahaman materi (Ho \& Hedberg, 2005). Hal yang sama pada mahasiswa. Mahasiswa perlu diberi kesempatan dan pengalaman untuk belajar memecahkan masalah-masalah agar kemampuannya meningkat (Krulik, et al., 2003), 
Mahasiswa juga perlu belajar memecahkan masalah menggunakan tahaptahap Polya yaitu memahami masalah, membuat rencana, melaksanakan rencana, dan memeriksa kembali (Polya, 1973; Posamenteir \& Krulik, 2009). Dosen perlu membimbing mahasiswa di setiap tahap tersebut dengan mengajukan pertanyaanpertanyaan, atau meminta mahasiswa untuk melakukan aktivtias tertentu. Sebagai contoh pada tahap memahami masalah, dosen membimbing mahasiswa dengan mengajukan pertanyaan-pertanayan: “apa yang diketahui dari masalah?”, “apa yang ditanya?", atau “apa informasi penting dari masalah?". Dosen juga bisa meminta mahasiswa untuk menyatakan masalah dalam bentuk gambar, simbol, atau persamaan matematis tertentu (Polya, 1981).

Begitu pula, kemampuan siswa-siswa dalam memecahkan masalah meningkat pada pembelajaran yang menjadikan pemecahan masalah sebagai tujuan utamanya. Pembelajaran tersebut antara lain pembelajaran berbasis masalah (problem based learning), atau pembelajaran pengajuan masalah (problem posing) (Prayanti, Sadra, \& Sudiarta, 2014; Prayitno, 2006; Sahrudin, 2014). Kondisi demikian berlaku juga pada perkuliahan yang dilakukan oleh dosen.

Hasil penelitian juga menunjukkan bahwa tidak ada mahasiswa yang tergolong pemecah masalah yang baik pada akhir perkuliahan semester 1. Ini terjadi karena tidak ada mahasiswa yang menjawab benar pada masalah 6 yang merupakan masalah berakhir terbuka. Mahasiswa perlu belajar dan memiliki pengalaman dalam memecahkan masalah-masalah tersebut dengan berbagai pendekatan atau strategi, dan didorong untuk mengembangkan lebih dari satu rencana penyelesaian agar memiliki kemampuan dalam menyelesaikan masalahmasalah berakhir terbuka (King, et al., 2016).

\section{KESIMPULAN DAN SARAN}

Hasil penelitian menunjukkan bahwa rata-rata skor mahasiswa program studi pendidikan matematika angkatan 2016 dalam memecahkan masalah pada awal dan akhir semester 1 secara berturut-turut sebesar 7,97 dan 9,18 (skala 0 24). Hasil analisis menggunakan uji perbandingan dua sampel berpasangan 
menunjukkan ada peningkatan skor mahasiswa tersebut dalam memecahkan masalah dari awal dan akhir semester 1 tahun ajaran 2016/2017.

Persentase mahasiswa yang tergolong pemecah masalah yang rutin meningkat dari $83,1 \%$ di awal menjadi $91,5 \%$ di akhir semester 1 . Peningkatan tersebut terjadi karena $8,4 \%$ pemecah masalah yang kurang berpengalaman meningkat kemampuannya menjadi pemecah masalah yang rutin. Akan tetapi, peningkatan tersebut tidak terjadi pada pemecah masalah yang baik dimana tetap tidak ada mahasiswa yang tergolong pemecah masalah ini di awal dan akhir semester 1. Hal tersebut terjadi karena tidak ada mahasiswa yang menjawab benar pada masalah 6 yang merupakan masalah berakhir terbuka.

Dosen seharusnya menerapkan perkuliahan yang memberi kesempatan dan pengalaman pada mahasiswa-mahasiswa untuk menyelesaikan masalah tertutup atau masalah berakhir terbuka dengan pendekatan atau strategi yang berbedabeda. Dosen perlu membimbing mahasiswa untuk menyelesaikan masalah di setiap tahap pemecahan masalah mulai dari memahami masalah, membuat rencana, melaksanakan rencana, dan memeriksa kembali. Lebih lanjut, dosen seharusnya mendorong mahasiswa untuk menyelesaikan suatu masalah dengan lebih dari satu cara.

\section{DAFTAR PUSTAKA}

Bush, W. S., dan Greer, A. S. (Eds.), Mathematics Assessment. A Practical Handbook for Grade 9-12, The National Council of Teachers of Mathematics Inc. Reston, VA., 1999.

Charles, R., Lester, F., dan O'Daffer, P., How to Evaluate Progress in Problem Solving, The National Council of Teachers of Mathematics, Inc., Reston, VA., 1987.

Cohen, L., Manion, L., dan Morrison, K., Research Methods in Education, Edisi Kenam, Routledge, New York, NY., 2007.

Florida Deparment of Education, Classroom Cognitive and Metacognitive Strategies for Teachers, Tallahassee, Bureau of Exceptional Education and Student Services, Florida, 2010. 
Ho, K. F. dan Hedberg, J. G., Teachers' Pedagogies and Their Impact on Students' Mathematical Problem Solving, Journal of Mathematical Behaviour, 24 (2005), 238-252, doi:10.1016/j.jmathb.2005.09.006.

Kennedy, L. M., Tipps, S., dan Johnson, A., Guiding Children's Learning of Mathematics, Edisi Kesebelas, Thomson Wadsworth, Belmont, C.A., 2008.

King, F. J., Goodson, L., dan Rohani, F., Higher Order Thinking Skills, 2016, http://www.cala.fsu.edu/files/higher_order_thinking_skills.pdf, diakses pada 30 Maret 2016.

Krulik, S., Rudnick, J., dan Milou, E., Teaching Mathematics in Middle Schools. A Practical Guide, Pearson Education Inc., Boston, MA., 2003.

Lerch, C. M., Control Decisions and Personal Beliefs: Their Affect on Solving Mathematics Problem, Journal of Mathematical Behaviour, 23(1) (2004), 21-36. doi:10.1016/j.jmathb.2003.12.002.

Lodico, M. G., Spaulding, D. T., dan Voegtle, K. H., Method in Educational Research: from Theory to Practice, John Willey \& Sons, Inc., San Francisco, C.A., 2006.

Mairing, J. P., Budayasa, I. K., dan Juniati, D., Profil Pemecahan Masalah Peraih Medali OSN, Jurnal Pendidikan dan Pembelajaran, 18(1) (2011), 65-71.

Mairing, J. P., Budayasa, I. K., dan Juniati, D., Perbedaan Profil Pemecahan Masalah Peraih Medali OSN Matematika berdasarkan Jenis Kelamin, Jurnal Ilmu Pendidikan, 18(2) (2012), 125-134, doi:10.17977/jip.v18i2.3612.

Marzano, R. J., Pickering, D., dan McTighe, J., Assessing Student Outcomes, Association for Supervision and Curriculum Development, Alexandria, V.A., 1993.

Ministry of Education, A guide to Effective Instruction in Mathematics Kindergarten to Grade 6, Volume Two: Problem Solving and Communication, Ontario Ministry of Education, Toronto, Canada, 2006.

Muir, T., Beswick, K., dan Williamson, J., I am not Very Good at Solving Problems: An Exploration of Student's Problem Solving Behaviours, The 
Journal of Mathematical Behaviour, 27(3) (2008), 228-241, doi:10.1016/j.jmathb.2008.04.003.

Musser, G. L., Burger, W. F., dan Peterson, B. E., Mathematics for Elementary Teachers, a Contemporary Approach, Edisi Kesembilan, John Wiley \& Sons, Inc., Hoboken, NJ, 2011.

National Council of Teachers of Mathematics, Principles and Standards for School Mathematics, The National Council of Teachers of Mathematics, Inc., Reston, V.A., 2000.

Pimta, S., Tayruakham, S., dan Nuangchalerm, P., Factors Influencing Mathematics Problem Solving Ability of Sixth Grade Students, Journal of Social Sciences, 5(4) (2009), 381-385.

Polya, G., How to Solve It, Edisi Kedua, Princeton University Press, Princeton, NJ, 1973.

Polya, G., Mathematical Discovery: On Understanding, Learning and Teaching Problem Solving, John Wiley \& Sons, Inc, New York, NY, 1981.

Posamenteir, A. S. dan Krulik, S., Problem Solving in Mathematics Grades 3-6, Powerful Strategies to Deepen Understanding, Corwin A SAGE Company, Thousand Oaks, CA, 2009.

Prayanti, N. P., Sadra, T. W., dan Sudiarta, I. G., Pengaruh Strategi Pembelajaran Pemecahan Masalah Berorientasi Masalah Matematika Terbuka terhadap Kemampuan Pemecahan Masalah Ditinjau dari Keterampilan Metakognitif Siswa kelas VII SMP Sapta Andika Denpasar Tahun Pelajaran 2013/2014, eJournal Program Pascasarjana Universitas Pendidikan Ganesha, 3(1) (2014).

Prayitno, S., Model Pembelajaran Berbasis Masalah untuk Meningkatkan Aktivitas dan Hasil Belajar pada Perkuliahan Teori Peluang. Jurnal Kependidikan, 36(2) (2006), 223-226.

Sa'dijah, C. dan Sukoriyanto, Asesmen Pembelajaran Matematika, UM Press, Malang, Indonesia, 2015. 
Sahrudin, A., Implementasi Strategi Pembelajaran Discovery untuk Meningkatkan Kemampuan Pemecahan Masalah Matematis dan Motivasi Belajar Siswa SMA, Jurnal Pendidikan Unsika, 2(1) (2014), 1-12.

Van De Walle, J. A., Karp, K. S., dan Bay-Williams, J. M., Elementary and Middle School Mathematics: Teaching Developmentally, Edisi Ketujuh, Ally \& Bacon, Boston, MA, 2010. 